\title{
Chronic migraine headache and multiple dental pathologies causing cranial pain for 35 years: the neurodental nexus
}

\author{
Antonio Jose Reyes, ${ }^{1}$ Kanterpersad Ramcharan, ${ }^{\circledR}{ }^{2}$ Rajesh Maharaj ${ }^{3}$
}

${ }^{1}$ Medicine, Neurology Unit, San Fernando Teaching Hospital, San Fernando, Trinidad and Tobago ${ }^{2}$ Medicine, SurgiMed Clinic, San Fernando, Trinidad and Tobago ${ }^{3}$ Independent Researcher, Chaguanas, Trinidad and Tobago

\section{Correspondence to}

Dr Kanterpersad Ramcharan kramcharan79@yahoo.com

Accepted 8 September 2019

\section{Check for updates}

(c) BMJ Publishing Group Limited 2019. No commercial re-use. See rights and permissions. Published by BMJ.

To cite: Reyes AJ,

Ramcharan K,

Maharaj R. BMJ Case

Rep 2019;12:e230248

doi:10.1136/bcr-2019-

230248

\section{SUMMARY}

We report a case that illustrates how chronic migraine headaches and multiple dental pathologies caused severe and long-standing cranial pain that affected the quality of life of a man for more than 35 years. His case was investigated at several settings including the neurology outpatient clinic of the hospital without a definitive diagnosis or resolution. After investigations, multiple oral pathologies including two occult dental abscesses were diagnosed. Once both affected teeth and associated abscesses were surgically removed, with subsequent antibiotic therapy the headaches resolved.

\section{BACKGROUND}

Millions of patients suffering from headache attend the neurology clinics around the world and often receive chronic, ineffective and empirical treatment because the medical investigations are unable to reveal the cause of their cranial symptoms. Clinical judgement is paramount in making a diagnosis as the causes of headaches are myriad. ${ }^{12}$ Many medical algorithms to assist with diagnosis have been published. However, the suspicion of occult oral pathology can be a clue to the underlying aetiopathogenesis of cranial pains. Oral pathologies causing headaches include cavities, bone loss due to periodontal disease, abscesses, impacted teeth, cysts and tumours. Chronic pulp infection caused by low virulent pyogenic organisms may cause tissue changes so indolently that recognisable symptoms do not manifest for a considerable period of time. ${ }^{1-8}$ The ability of oral pathology to cause or contribute to the prolongation of the headache was overlooked in this case, which serves as a reminder of an important clinical lesson. We report a clinical case that illustrates how the presence of multiple oral pathologies suggested a referral to an oral surgeon for further evaluation and resolution of a severe and long-standing cranial pain that affected the quality of life of a man for more than 35 years. We here emphasise methods to diagnose occult oral pathology associated to headaches. Indeed, out of 17000 cases published in the British Medical Journal Case Report, a Pubmed search showed 466 cases with headaches as a keyword, and none were related to dental pathology, so prompting this report.

\section{CASE PRESENTATION}

A 64-year-old man attended the neurology outpatient clinic of the hospital for severe chronic migraine headache for the last 35 years without proper response to multiple analgesic agents. During this time, he had several dental extractions and restorations but without relief from his cranial pain despite taking the combination of oral acetaminophen $250 \mathrm{mg}$, aspirin $250 \mathrm{mg}$ and caffeine $65 \mathrm{mg}$, three times per day. Lately, he was taking $60 \mathrm{mg}$ codeine phosphate hemihydrate and $1 \mathrm{~g}$ of paracetamol three times per day without appropriate response. He never thought nor was he informed that his cranial pain was aggravated and prolonged by his dental pathologies. More recently, several teeth were treated with root canal procedures and more restorations. As time elapsed, the headache became more frequent and more severe, until he was having three to five episodes per week. The attacks began during the morning or evening and continued for 1-3 days, especially if analgesics were not used. The pain usually started gradually in the temporal regions bilaterally and radiated to the frontal and parietal regions, respectively. The pain was always more severe on the right side. The headaches had no additional accompanying autonomic symptoms such as conjunctival injection, lacrimation, nasal congestion, rhinorrhoea or forehead and facial sweating. The headache pattern fulfilled the four diagnostic criteria for chronic migraine headache according to the International Classification of Headache Disorders 3rd Edition (ICHD-3):

(A) The migraine-like headache was present for more than 15 days per month for more than 3 months. (B) The patient has had at least five attacks fulfilling criteria B-D for migraine without aura (1.1 ICHD-3): the untreated headache attacks were moderate to severe pain intensity, pulsating in character, lasted 4-72 hours, accompanied by nausea and exacerbated by walking around. (C) The headache was present more than 8 days per month for more than 3 months, fulfilling the criteria $\mathrm{C}$ and $\mathrm{D}$ for 1.1 migraine without aura according to the CHD-3. The patient was believed to be suffering from migraine at onset which was relieved by sumatriptan, but this drug was stopped due to severe dizziness. (D) Headache pattern was not better accounted for by another ICHD-3 diagnosis. The pre-existing primary headache lasted several years. However, the frequency and severity of the 


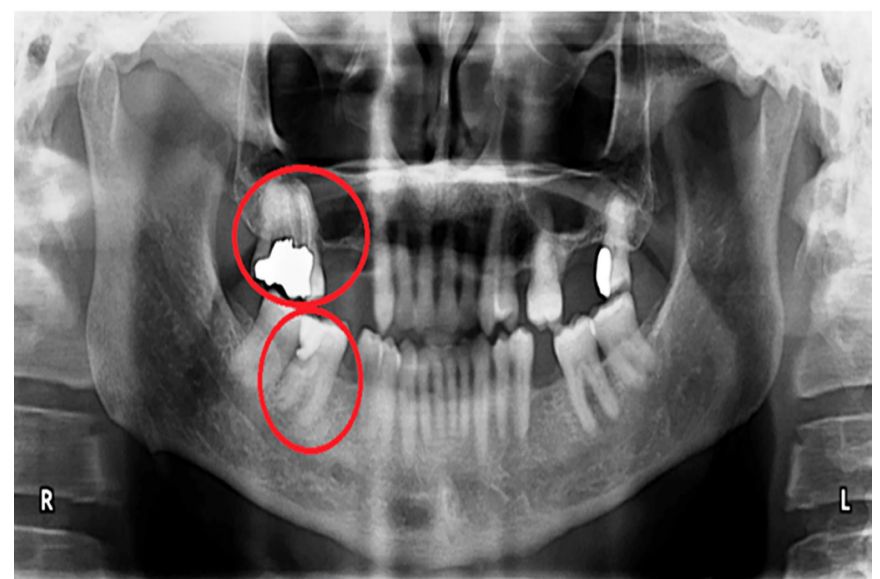

Figure 1 Presurgical panoramic X-ray showing multiple edentulous spaces, amalgam restorations, two teeth with necrotic pulps (see red circles) and one root filled upper right second molar.

headaches increased in close temporal relation to the manifestations of dental pathologies. The headaches also improved significantly after every dental intervention, but the headaches persisted. These findings suggested the presence of an associated secondary headache.

After analysis, the patient also fulfilled the general diagnostic criteria for secondary headaches: (A) Any headache fulfilling criterion $\mathrm{C}$, in other words not better accounted for by another ICHD-3 diagnosis. (B) Evidence of causation demonstrated by at least two of the following: (1) the chronic headache had developed in temporal relation to the onset of the multiple oral pathologies.;(2) the headache had significantly worsened in parallel with worsening of the multiple oral pathology throughout the years with significantly improvement in parallel with dental intervention; (3) the headache had characteristics typical for oral pathology associated to sensitisation of the trigeminal nerve and (4) presence of other evidence of causation such as the headache was treated with multiple analgesic agents without effective long-term outcome except for dental intervention, complete resolution of headache after full restoration of oral health without return after 24 months, and no family history of similar headache. The multiple oral pathologies managed in our patient were carious teeth with multiple restorations, extractions, root canal treatments and two dental abscesses.

He had a history of brachytherapy for prostate cancer and surgical intervention with chemotherapy for colon cancer 5 and 2 years previously. He also suffered from essential hypertension

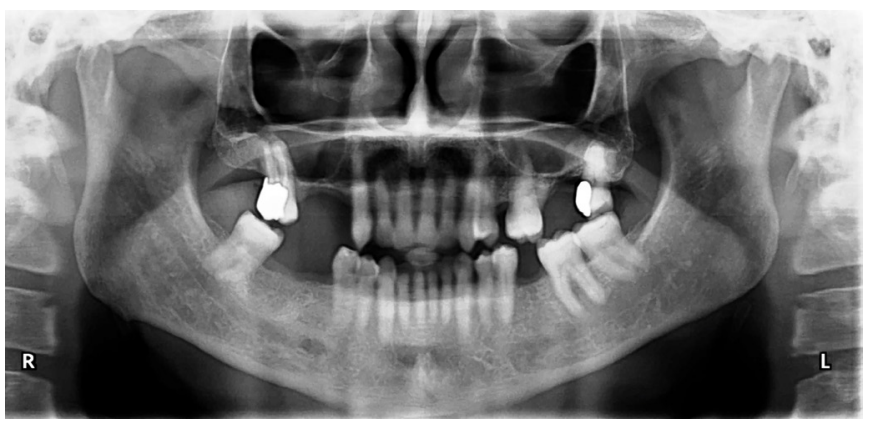

Figure 2 Postsurgical panoramic X-ray after upper right third molar and lower right second molar were extracted. Edentulous spaces, root filled upper right second molar, deep amalgam restoration on upper left third molar and remaining teeth are also shown. for the last 5 years and well controlled with $10 \mathrm{mg} /$ day of enalapril orally. He had no previous history of neurological diseases or consumption of alcohol, tobacco products, recreational drugs or exposure to chemicals.

On examination, he was alert, and oriented to time, person and place, with a Glasgow Coma Scale of $15 / 15$. The patient was afebrile $\left(36.2^{\circ} \mathrm{C}\right)$ and in sinus rhythm $(85$ beats $/ \mathrm{min})$ with a blood pressure of $135 / 75 \mathrm{~mm} \mathrm{Hg}$. Respiratory rate was 28 breaths/min and oxygen saturation $100 \%$ on room air. Body mass index was $27 \mathrm{~kg} / \mathrm{m}^{2}$. A neuro-ophthalmological examination was normal. Pupils were symmetrically shaped and normally reactive to light bilaterally. Examination of the mouth showed no evidence of gingival or other oral diseases or tumour. The remaining teeth had extensive restorations. Percussion of the teeth produced no 'trigger zones of pain or reaction'. The cranial pain was not modified with passive or assisted jaw movement, function or parafunction. There was no family history of temporomandibular disorder.

No other relevant findings on physical examination were found. The patient was finally diagnosed suffering from a chronic migraine headache without aura (1.3 ICHD-3) that was persistently prolonged by multiple oral facial pathologies (11.9 ICHD-3) that involved the trigeminal nervous system.

The patient's oral surgeon was informed, and two abscesses were detected after physical and radiological examinations (figure 1). The upper right third molar and lower right second molar associated with the abscesses were surgically extracted (figure 2). Antibiotic therapy was completed with $875 \mathrm{mg}$ of amoxicillin and $125 \mathrm{mg}$ of clavulanate potassium orally two times per day for 10 days. His periodontal health was improved by supragingival/subgingival scaling and oral hygiene instruction. The headaches improved gradually and currently, 24 months later, the patient is free of pain without analgesic agents or recurrences.

\section{INVESTIGATIONS}

Extensive investigations are shown in table 1.

\section{DIFFERENTIAL DIAGNOSIS}

Evaluation of headache was made according to the ICHD-3. ${ }^{1}$ All differentials were ruled out (table 2), and the patient was diagnosed suffering from chronic migraine headache (1.3 ICHD-3) and multiple dental pathology (11.6 ICHD-3) causing chronic pains for 35 years.

\section{TREATMENT}

Relevant treatment included surgical removal of necrotic teeth with dental abscesses, restoration of carious teeth with amalgam/ composite, and root canal treatments were evaluated for success and periodontal care. Antibiotic and analgesic therapy was administrated accordingly and successfully.

\section{OUTCOME AND FOLLOW-UP}

The patient made an uninterrupted recovery after surgery and was discharged from the neurology and dental clinics. He has been entirely free from headaches and remarked 24 months later that his quality of life had improved.

\section{DISCUSSION}

Headaches are among the most common disorders of the nervous system. It has been estimated that almost half of the adult population have had a headache at least once in a given year. $^{2}$ Tension headaches are the most common, affecting 
Table 1 Medical investigations

\begin{tabular}{|c|c|c|}
\hline Blood test & Result & Reference range \\
\hline White cell count & $8.6 \times 10^{9} / \mathrm{L}$ & $4.5-11.0 \times 10^{9} / \mathrm{L}$ \\
\hline Haemoglobin & $162 \mathrm{~g} / \mathrm{L}$ & $140-175 \mathrm{~g} / \mathrm{L}$ \\
\hline $\begin{array}{l}\text { Mean corpuscular } \\
\text { volume }\end{array}$ & $81.2 \mathrm{fL} / \mathrm{red}$ cell & 80-96 fL/red cell \\
\hline Platelets count & $329 \times 10^{9} / \mathrm{L}$ & $156-373 \times 10^{9} / \mathrm{L}$ \\
\hline Serum potassium & $4.5 \mathrm{mmol} / \mathrm{L}$ & $3.5-5.1 \mathrm{mmol} / \mathrm{L}$ \\
\hline Serum sodium & $145 \mathrm{mmol} / \mathrm{L}$ & $135-145 \mathrm{mmol} / \mathrm{L}$ \\
\hline Serum creatinine & $0.8 \mathrm{mg} / \mathrm{dL}$ & $0.5-1.2 \mathrm{mg} / \mathrm{dL}$ \\
\hline Blood urea nitrogen & $12 \mathrm{mg} / \mathrm{dL}$ & $3-20 \mathrm{mg} / \mathrm{dL}$ \\
\hline Uric acid & $3.8 \mathrm{mg} / \mathrm{dL}$ & $2.5-8 \mathrm{mg} / \mathrm{dL}$ \\
\hline $\begin{array}{l}\text { Alanine } \\
\text { aminotransferase }\end{array}$ & $40 \mathrm{IU} / \mathrm{L}$ & $20-60 \mathrm{IU} / \mathrm{L}$ \\
\hline $\begin{array}{l}\text { Aspartase } \\
\text { aminotransferase }\end{array}$ & $33 \mathrm{IU} / \mathrm{L}$ & $5-40 \mathrm{IU} / \mathrm{L}$ \\
\hline $\begin{array}{l}\text { Gamma } \\
\text { glutamyltranspeptidase }\end{array}$ & $38 \mathrm{U} / \mathrm{L}$ & $8-61 \mathrm{IU} / \mathrm{L}$ \\
\hline Lactate dehydrogenase & $320 \mathrm{IU} / \mathrm{L}$ & $105-333 \mathrm{IU} / \mathrm{L}$ \\
\hline Alkaline phosphatase & $296 \mathrm{U} / \mathrm{L}$ & 40-129 IU/L \\
\hline Total bilirubin & $1.2 \mathrm{mg} / \mathrm{dL}$ & $0.2-1.3 \mathrm{mg} / \mathrm{dL}$ \\
\hline Direct bilirubin & $0.40 \mathrm{mg} / \mathrm{dL}$ & $0.0-0.4 \mathrm{mg} / \mathrm{dL}$ \\
\hline Albumin & $4.5 \mathrm{~g} / \mathrm{dL}$ & $3.5-5.5 \mathrm{~g} / \mathrm{dL}$ \\
\hline $\begin{array}{l}\text { Albumin-corrected } \\
\text { calcium }\end{array}$ & $9.6 \mathrm{mg} / \mathrm{dL}$ & $9.6-11.2 \mathrm{mg} / \mathrm{dL}$ \\
\hline C-reactive protein & $1.0 \mathrm{mg} / \mathrm{dL}$ & $0.0-1.0 \mathrm{mg} / \mathrm{dL}$ \\
\hline Rheumatoid factor & $398 \mathrm{U} / \mathrm{mL}$ & $\begin{array}{l}\text { 1. Negative: less than } \\
40 \mathrm{IU} / \mathrm{mL}\end{array}$ \\
\hline Fasting glycaemia & $89 \mathrm{mg} / \mathrm{dL}$ & $60-120 \mathrm{mg} / \mathrm{dL}$ \\
\hline $\begin{array}{l}\text { Erythrocyte } \\
\text { sedimentation rate }\end{array}$ & $10 \mathrm{~mm} /$ hour & $\begin{array}{l}\text { Normal: less than } 15 \mathrm{~mm} / \\
\text { hour }\end{array}$ \\
\hline $\begin{array}{l}\text { Venereal disease } \\
\text { research laboratory test }\end{array}$ & Non-reactive & Non-reactive or reactive \\
\hline $\begin{array}{l}\text { Fluorescent Treponema } \\
\text { pallidum antibody } \\
\text { absorption }\end{array}$ & Negative & Positive or negative \\
\hline HIV ELISA & Negative & Positive or negative \\
\hline Antistreptolysin 0 titre & $73 \mathrm{IU} / \mathrm{mL}$ & $0-200 \mathrm{IU} / \mathrm{mL}$ \\
\hline $\begin{array}{l}\text { Antidouble-stranded } \\
\text { DNA }\end{array}$ & Negative & Positive or negative \\
\hline Antinuclear antibody & Negative & Positive or negative \\
\hline Antinuclear factor & Negative & Positive or negative \\
\hline $\begin{array}{l}\text { Perinuclear } \\
\text { antineutrophil } \\
\text { cytoplasmic antibodies }\end{array}$ & $5.41 \mathrm{U} / \mathrm{mL}$ & $\begin{array}{l}\text { Negative: less than } 10.0 \mathrm{U} / \\
\mathrm{mL}\end{array}$ \\
\hline $\begin{array}{l}\text { Cytoplasmic } \\
\text { antineutrophil } \\
\text { cytoplasmic antibodies }\end{array}$ & $6.23 \mathrm{U} / \mathrm{mL}$ & $\begin{array}{l}\text { Negative: Less than } 10.0 \mathrm{U} / \\
\mathrm{mL}\end{array}$ \\
\hline $\begin{array}{l}\text { Prostate-specific antigen } \\
\text { test }\end{array}$ & $1.8 \mathrm{ng} / \mathrm{mL}$ & $\begin{array}{l}\text { Negative: less than } 4.0 \mathrm{ng} / \\
\mathrm{mL}\end{array}$ \\
\hline Other investigations & Result & Reference range \\
\hline ECG & Normal & Normal or abnormal \\
\hline Chest X-ray & Normal & Normal or abnormal \\
\hline C-spine X-rays & Normal & Normal or abnormal \\
\hline CT scan of the brain & Normal & Normal or abnormal \\
\hline $\begin{array}{l}\text { MRI/MR angiography/ } \\
\text { MR venography scan of } \\
\text { the brain }\end{array}$ & Normal & Normal or abnormal \\
\hline $\begin{array}{l}\text { Carotid Doppler } \\
\text { ultrasound }\end{array}$ & Normal & Normal or abnormal \\
\hline Echocardiogram & $\begin{array}{l}\text { Normal ejection fraction } \\
(\mathrm{EF}): 75 \%\end{array}$ & Normal or abnormal \\
\hline
\end{tabular}

Table 2 Classification of headache according to International Classification of Headache Disorders 3rd Edition

\begin{tabular}{|c|c|}
\hline Origin & Type of headache \\
\hline The primary headaches & $\begin{array}{l}\text { 1. Migraine: without aura, with aura, } \\
\text { chronic, with complications (status } \\
\text { migrainosus, migrainous infarction, } \\
\text { persistent aura without infraction } \\
\text { and migraine aura-triggered seizure), } \\
\text { probable migraine without or with aura } \\
\text { and episodic syndromes that may be } \\
\text { associated with migraine. } \\
\text { 2. Tension-type headache. } \\
\text { 3. Trigeminal autonomic cephalalgias. } \\
\text { 4. Other primary headache disorders } \\
\text { such as headaches associated to cough, } \\
\text { exercise, sexual activity, thunderclap, } \\
\text { cold stimulus, external pressure, stabbing, } \\
\text { nummular, hypnic and new daily } \\
\text { persistent. }\end{array}$ \\
\hline Secondary headaches & $\begin{array}{l}\text { 5. Headache attributed to trauma or } \\
\text { injury to the head and/or neck. } \\
6 \text {. Headache attributed to cranial or } \\
\text { cervical vascular disorder. } \\
\text { 7. Headache attributed to non-vascular } \\
\text { intracranial disorder. } \\
\text { 8. Headache attributed to a substance or } \\
\text { its withdrawal. } \\
\text { 9. Headache attributed to infection. } \\
\text { 10. Headache attributed to disorder of } \\
\text { homoeostasis. } \\
\text { 11. Headache or facial pain attributed to } \\
\text { disorder of the cranium, neck, eyes, ears, } \\
\text { nose, sinuses, teeth, mouth or other facial } \\
\text { or cervical structure. } \\
\text { 12. Headache attributed to psychiatric } \\
\text { disorder. }\end{array}$ \\
\hline Neuropathies and facial pains & $\begin{array}{l}\text { 13. Painful lesions of the cranial nerves } \\
\text { and other facial pain. } \\
\text { 14. Other headache disorders. }\end{array}$ \\
\hline
\end{tabular}

about 1.6 billion people ( $21.8 \%$ of the population) followed by migraine headaches which affect about 848 million $(11.7 \%){ }^{3}$ The direct and indirect costs of headaches have been estimated at approximately \$17billion per year. Missed workdays and medical benefits associated with headache cost American industry approximately $\$ 50$ billion annually. ${ }^{4}$ Over 100000 people are absent from work or school because of headaches every working day in the UK. The cost to the UK economy may exceed $£ 1.5$ billion per annum. ${ }^{5-7}$ Worldwide, a minority of people with headache disorders are diagnosed appropriately by a healthcare provider. ${ }^{2}$ Headache is perhaps the most frequent reason for a patient to attend the neurology clinic and yet in many cases, their true aetiopathogenesis is unknown or unclear. Persistent cranial symptoms should prompt adequate oral examination and consultation. ${ }^{89}$ If the consultation proves negative, then further and more detailed medical studies such as autoimmune screen, vasculitis screen, radiological studies and or temporal arterial biopsy can be initiated.

Although, our patient headache attacks were manifested without aura or autonomic symptoms, the headache pattern fulfilled the four diagnostic criteria for chronic migraine headache according to the ICHD-3. The supportive evidence of causation was that the headache was unresponsive to multiple analgesic agents, with success achieved after dental intervention led to complete resolution of headache without relapse after 24 months follow-up. There was no family history of similar 
headache. The patient did not fulfil the diagnostic criteria for the most common pain related temporomandibular disorders according to the recommendations of the International Research Diagnostic Criteria for Temporomandibular Disorder Consortium Network and Orofacial Pain Special Interest Group. ${ }^{10}$

The patient was finally diagnosed suffering from a chronic migraine headache without aura (1.3 ICHD-3) that was persistently prolonged by multiple oral facial pathology (11.9 ICHD-3) that involved the trigeminal nervous system. ${ }^{1}$ Many cases of severe and long-standing headache may be due to occult dental infection or other oral pathology. 89 Multiple dental pathologies can be contributing factors or the clue to the underlying aetiopathogenesis of a severe and long-standing headache. Major dental problems that can be detected with an oral examination and radiographic studies are cavities, bone loss due to periodontal disease, abscesses, impacted teeth, cysts and tumours. Under certain circumstances, chronic pulp infection caused by low virulent pyogenic organisms may cause periradicular tissue changes that can be so indolent, subclinical or occult for a considerable time. This phenomenon is especially seen in immunocompetent patients such as in our clinical case.

Headaches and toothaches are all transmitted from the same nerve, the trigeminal nerve. It is a well-recognised phenomenon that migraine can occur in V2 and V3 distributions of the trigeminal nerve mimicking toothache, but there are rare reports of toothache presenting as headaches. Another well-recognised phenomenon is that any painful insult to the territory of the trigeminal nerves can precipitate headaches in those patients susceptible of headache conditions. On the other hand, most clinicians would exclude orofacial pathology when diagnosing trigeminal pain and recent onset headaches.

The pathophysiological process of migraine is not fully understood, and the same to chronic migraine. However, all recent data indicate that migraine is a disorder of brain dysfunction with both the genetic predisposition and with environmental trigger factors. Both recurring headache attacks and the comorbid conditions (medication overuse, insufficient migraine prophylactic treatment, anxiety and depression) promote the derangement of top-down pain modulation and atypical release of nociceptive molecules, which aggravates trigeminal sensitisation induced by repeated nociceptive inputs. Among these nociceptive insults affecting the primary and secondary trigeminal afferents are multiple oral dental pathologies such as in our case. Chronic abscesses cause local inflammatory process, necrotic tissue, releasing of pain mediators and local tissue hypoxia. These abnormalities can affect the trigemino-vascular system with subsequent perpetuation of the neurovascular hypersensitivity. With this hypersensitive state, the episodic migraine finally progresses to a chronic migraine that can be aggravated and prolonged in time by the chronic oral diseases. Although recent evidence using electrophysiology and neuroimaging have indicated that cortical hyperexcitability (somatosensory and visual cortices), brainstem dysfunction, and central sensitisation are important in the development of chronic migraine, it is also well known that a large proportion of patients suffering from chronic migraine report cutaneous allodynia, illustrating that sensitisation of the trigeminal system also occurs. ${ }^{6}$ The mechanisms underlying the structural alterations remain to be elucidated to determine whether they are the cause or effect of migraine chronification and whether they can also serve as markers for migraine phenotypes, evolution and prognosis. ${ }^{6}$ In addition, several molecules, such as calcitonin gene-related peptide and the serotonin system, have been reported to be correlated with migraine perpetuation. ${ }^{6}$ Once the migraine becomes well established as chronic, the treatment response becomes less effective. Therefore, in the management of chronic migraine, the first and most important step is to avoid the development of chronic migraine by rigorous control of risk factors, including sufficient pain relief, timely prophylactic therapy, effective management of mood disorder and other comorbidities. However, multiple chronic dental pathologies and/or occult oral pathology can compromise this preventative approach. Only after the oral diseases were completely resolved, the therapeutic approach to chronic migraine became effective. This may be an evidence in favour of the presence of sensitisation of the trigemino-vascular system in our patient. The role of the cortical hyperexcitability, brainstem dysfunction and other mediators are areas of further research. ${ }^{6}$

The diagnosis of cranial pain in our patient required a multidisciplinary approach that only was achieved when the dentist was contacted directly by the neurologist. The ability of oral pathologies to cause or contribute to the prolongation of the headache was overlooked in this case, which serve as a reminder of an important clinical lesson. ${ }^{8-12}$ Healthcare service providers should consider oral pathology as cause or aggravating factors for headaches. It is also necessary that dentists, orofacial specialists and maxillofacial surgeons go beyond the mouth and investigate the presence of cranial pains among their patients and refer them to the neurology clinic for further assessment and management. Occasionally, the patient may remember that the tooth had ached at times before being restored, they could not chew or bite down on the tooth or that the process of restoring was accompanied by a great deal of pain that might indicate deep caries or direct pulp exposure. The dentist may have had to perform a direct or indirect 'pulp cap', and there may have been sensitivity for weeks or months after the procedure. Such teeth may have irreversible pulpitis or develop a necrotic pulp requiring root canal treatment or extraction. Dental pain is usually more severe at night. Pressure during mastication is variably painful. ${ }^{89}$ The origin of referred pain is commonly obscure and may be localised in or about the tooth or be present in any part of the face areas supplied by the trigeminal nerves. ${ }^{89}$

The present case emphasises the necessity for an adequate oral examination in orofacial pains where cranial symptoms, although not definitive, are persistent. When no cause can be found by medical examination of the usual extent, proper oral consultation should be sought. If the consultation proves negative, then further and more detailed investigations can be initiated. $^{13-15}$

Contributors All authors are responsible for the following: conception and design, acquisition of data or analysis and interpretation of data; drafting the article or revising it critically for important intellectual content; final approval of the version published and agreement to be accountable for the article and to ensure that all questions regarding the accuracy or integrity of the article are investigated and resolved.

Funding The authors have not declared a specific grant for this research from any funding agency in the public, commercial or not-for-profit sectors.

Competing interests None declared.

Patient consent for publication Obtained.

Provenance and peer review Not commissioned; externally peer reviewed.

\section{REFERENCES}

1 Headache Classification Committee of the International Headache Society. The International Classification of Headache Disorders 3rd edition. Cephalalgia, 2018:1-211

2 World Health Organization (WHO). "Headache disorders Fact sheet N²77". 2106 http://www.who.int/mediacentre/factsheets/fs277/en/ 


\section{Learning points}

- Headache has been underestimated, under-recognised and undertreated throughout the world. Severe and persistent headaches, as in our case, are associated with personal and societal burdens of pain, disability, damaged quality of life and great financial cost.

- Many cases of severe and long-standing headaches can be due to occult oral pathology which can be difficult to diagnose and may represent an important proportion of patients attending the neurology clinic worldwide.

- Occult dental pathology causing or aggravating headaches can be kept hidden even from the dentist and in those suspicious cases a thorough dental history, head, neck and oral examination, panoramic and/or periapical dental X-rays and pulp vitality testing can assist in finding the contributing factors and the source of the problem.

3 Global Burden of Disease Study 2013 Collaborators. Global, regional, and national incidence, prevalence, and years lived with disability for 301 acute and chronic diseases and injuries in 188 countries, 1990-2013: a systematic analysis for the Global Burden of Disease Study 2013. Lancet 2015;386:743-800.

4 Solomon GD, Cady RK, Klapper JA, et al. Standards of care for treating headache in primary care practice. National Headache Foundation. Cleve Clin J Med 1997;64:373-83.
5 MacGregor EA, Steiner TJ, Davies PTG. Guidelines for All Healthcare Professionals in the Diagnosis and Management of Migraine, Tension-Type Headache, Cluster Headache, Medication-Overuse Headache. $3^{\text {rd }}$ ed. England and Wales: British Association for the Study of Headache (BASH), 2010. www.bash.org.uk

6 Su M, Yu S. Chronic migraine: A process of dysmodulation and sensitization. Mol Pain 2018:14:174480691876769.

7 Natoli JL, Manack A, Dean B, et al. Global prevalence of chronic migraine: a systematic review. Cephalalgia 2010;30:599-609.

8 Severe GRS. and Long-standing Headache due to Dental and Antral Infection. Br Med J 1946:1:526.

9 Eidelman D. The dental region constitutes a major blind spot in clinical medicine. Med Hypotheses 2006;66:912-4.

10 Schiffman E, Ohrbach R, Truelove E, et al. Diagnostic Criteria for Temporomandibular Disorders (DC/TMD) for Clinical and Research Applications: recommendations of the International RDC/TMD Consortium Network* and Orofacial Pain Special Interest Groupt. J Oral Facial Pain Headache 2014;28:6-27.

11 American Academy of Orofacial Pain. The American Academy of Orofacial Pain (AAOP) 174 S. New York Ave. POB 478 Oceanville, NJ 08231 609-504-1311. What is Orofacial pain? 2019 https://www.aaop.org.

12 Smetana GW. The diagnostic value of historical features in primary headache syndromes: a comprehensive review. Arch Intern Med 2000;160:2729-37.

13 Burstein R, Noseda R, Borsook D. Migraine: multiple processes, complex pathophysiology. J Neurosci 2015;35:6619-29.

14 Edlow JA, Panagos PD, Godwin SA, et al. Clinical policy: critical issues in the evaluation and management of adult patients presenting to the emergency department with acute headache. Ann Emerg Med 2008;52:407-36.

15 Woldeamanuel YW. Headache in Resource-Limited Settings. Curr Pain Headache Rep 2017:21:51.

Copyright 2019 BMJ Publishing Group. All rights reserved. For permission to reuse any of this content visit https://www.bmj.com/company/products-services/rights-and-licensing/permissions/ BMJ Case Report Fellows may re-use this article for personal use and teaching without any further permission.

Become a Fellow of BMJ Case Reports today and you can:

- Submit as many cases as you like

- Enjoy fast sympathetic peer review and rapid publication of accepted articles

- Access all the published articles

- Re-use any of the published material for personal use and teaching without further permission

Customer Service

If you have any further queries about your subscription, please contact our customer services team on +44 (0) 2071111105 or via email at support@bmj.com.

Visit casereports.bmj.com for more articles like this and to become a Fellow 